\title{
Soil properties and vegetable production with organic mulch and no-tillage system
}

\author{
Hajime ARAKI and Michiaki ITO
}

\begin{abstract}
Summary
Organic mulch was formed by mowing wheat straw and hairy vetch in a no-tillage field. Soil temperature under the organic mulch was constant, and the organic mulch decreased soil temperature in summer and early autumn and increased it in middle and late autumn compared with a bare and tilled field. The $\mathrm{pF}$ was maintained at 1.5-1.8 even in the dry weather of $\mathrm{Au}$ gust. Though much more release of inorganic nitrogen in the soil covered with organic mulch was recognized than in the bare and tilled field, there was no definite difference in the quantity of inorganic nitrogen released between the wheat straw and the hairy vetch mulch. Nitrogen concentration in lettuce produced in the hairy vetch mulch field was a little higher than that of lettuce in the bare and tilled field in autumn, 1995. Weed growth was suppressed effectively in the field covered with hairy vetch, and weed control was $53 \%$ in the wheat straw mulch field compared with that in the bare and tilled field. The yield of leaf lettuce (butter head), tomato and pod soybean in the hairy vetch mulch field was higher than in the wheat straw mulch field or the bare and tilled field.
\end{abstract}

\section{Introduction}

Some trials are under way for the establishment of a sustainable agriculture system. Some conservational tillage systems have been developed for reducing soil erosion and saving on farm energy use. The crop rotation and utilization of winter legume crop are very important in the LISA program ${ }^{1,2)}$. When autumn sowing cover crops such as legume and gramineous plants were mowed, killed by herbicide or died out naturally, organic mulch (not plowed, notilled soil covered with crop residue) will be formed in the field the following spring. Some crops have been produced in that condition, especially in the U.S.A.

Legume cover crops and gramineous plants have been used as a desiccated plant residue mulch (organic mulch) in a no-tillage system. It was reported that such organic mulch had some effects to improve soil environment, such as reducing soil erosion ${ }^{3,4)}$, improving soil organic content $^{5)}$, nitrogen availability ${ }^{6}$, increasing soil water-holding capacity ${ }^{7,8)}$, decreasing soil temperature ${ }^{9)}$, and reducing weed growth ${ }^{10,11}$. Increased crop yield was also reported in the culti. vation with a cover crop or organic mulch ${ }^{12,13,14)}$.

There are only a few reports on crop production with cover crop and organic mulch in Japan ${ }^{15,16)}$. When introducing an organic mulch system to crop production, it is necessary to consider environmental conditions such as climate and soil texture. Japan has much rain, yet sometimes water shortages are a concern outside of the rainy season (June and July).

In the present paper, we examined soil conditions formed by an organic mulch field with a no-tillage system, and investigated the possibility of vegetable production in that field.

Received Nov. 30, 1997

Accepted Dec. 12, 1998

University Farm, Niigata University, Muramatsu, Naka-kanbara, Niigata 959-1701, Japan 


\section{Materials and Methods}

1. Cultivation of cover crops and lettuce in organic mulch field in late autumn (1995)

Hairy vetch (Vicia villosa) and wheat (Triticum aestivum cv. mulchmugi) were sown in tilled field with no chemical fertilizer in the University Farm, Niigata University on 17 July, 1995, and grown for two months. The sowing rate of these plants was $5 \mathrm{~kg} / 10$ a. On 17 September, 1995, organic mulch was produced by mowing these plants, and the plant growth (dry weight of foliage) and weed control (dry weight of weed) under these plants were measured. Next, lettuce seedlings (Lactuca sativa cv. Ontario, crisp head type) were planted by hand in the field covered with organic mulch, with a $35 \mathrm{~cm}$ interval between plants and $50 \mathrm{~cm}$ row spacing, on 17 September. Growth of lettuce under the organic mulch was compared with that of lettuce planted in the bare and tilled soil. Leafy head weight of lettuce grown in the bare and tilled soil and the organic mulch field (no-tillage) was measured on 5 December, 1995. The nitrogen concentration in the outer leaves of lettuce and the soil $(10 \mathrm{~cm}$ depth) grown lettuce were examined with $\mathrm{C} / \mathrm{N}$ corder (Yanaco Co. Ltd., MT-700). Five plants in each plot were used for analysis of total nitrogen in leaves. Soil samples were collected from 4 points $(10 \mathrm{~cm}$ depth $)$ in each plot and mixed them. Plants and soil samples were dried at $70^{\circ} \mathrm{C}$ for 48 hours and filtrated through $0.2 \mathrm{~mm}$ stainless mesh for analysis by $\mathrm{C} / \mathrm{N}$ corder.

\section{Soil environment when covered with organic mulch}

On the following spring (1996), hairy vetch emerged and spread vines and leaves, and wheat elongated the culms. On 20 June, the foliage of hairy vetch and wheat were mowed with a bush cutter to form organic mulch (hairy vetch mulch and wheat straw mulch). The soil environment (soil temperature, soil moisture and nitrogen mineralization) was investigated mentioned below. Soil temperature was measured by an elec- tric precision long-term remote thermograph (CAT-P 147, Isuzu Seisakusho Co., Ltd.) from 29 July to 30 October. The temperature sensor of the thermograph was positioned underground (15 $\mathrm{cm}$ depth) in each field. Soil moisture $(\mathrm{pF})$ was investigated in the bare and tilled field and hairy vetch mulch field. A ceramic $\mathrm{pF}$ sensor (SPAD : PF 33, Fujiwara Co., Ltd.) was set underground (20 $\mathrm{cm}$ depth) in each field, and the $\mathrm{pF}$ was measured daily from 20 July to 31 August. On 5 October, 1996, the $10 \mathrm{~cm}$ depth soil samples were collected from 4 points in each field and dried in the greenhouse. Dried soil samples from 4 points in each field were mixed, and the mixed soil was used for nitrogen analysis. Then, the soil samples were incubated with the $60 \%$ of maximum water requirement at $30^{\circ} \mathrm{C}$. Incubated soil sample $(10 \mathrm{~g})$ was extracted with $100 \mathrm{ml}$ of $2 \mathrm{M}-\mathrm{KCl}$. The inorganic nitrogen was measured by the Indo-phenol method $\left(\mathrm{NH}_{4}-\mathrm{N}\right)$ and the Cadmicolumn method $\left(\mathrm{NO}_{3}-\mathrm{N}\right)$.

\section{Vegetable production in organic mulch field (1996)}

The seedlings of three vegetables, tomato (Licopersicon esculentum cv. Zuiko 102 grafted with root stock tomato cv. Joint), pod soybean (Glycine max cv. shinkohirakata) and lettuce (Lactuca sativa cv. Okayama-saradana, butter head type), were planted in the organic mulch field (hairy vetch mulch and wheat straw mulch), and their yields were measured in comparison to those in the bare and tilled field, respectively. The cultivating period was 3 July to 20 September in Tomato, 29 July to 7 October in pod soybean and 29 July to 20 August in butter head lettuce. Tomatoes formed in the 2nd to 4 th fruit cluster were harvested. Fungi were controlled with Bis-dithane [dizinc bis (dimethyldithio carbamate) ethylenebis (dithiocarbamate), Tokyo Yuki Co., Ltd.] in tomato and Sumitop-M [dimethyl 4,4'-0-phenylenebis (3-thioallo-phanate), Nihon Soda Co., Ltd. ]in pod soybean. Pests were controlled with Sumithion [MEP (dimethyl 4-nitro-m-tolyl phosphorothioate), Nissan 
Chemical Co., Ltd] in tomato and Diadinon [diethyl 2-isopropyl-4-methyl-6-pyrimidinyl phosphorothioate, Nissan Chemical Co., Ltd] in pod soybean.

The plot area was $40 \mathrm{~m}^{2}(2 \mathrm{~m} \times 20 \mathrm{~m})$ and no chemical fertilizer was added to the soil in 1995 and 1996. In each plot, 6-10 plants were measured for growth and yield, and this experiment was designed with 2 replications. The experiments were conducted at the University Farm, Niigata University, Muramatsu, Niigata Prefecture, volcanic soil (soil texture; $\mathrm{SiC}$ ).

\section{Results}

\section{Growth of cover crops and lettuce cultivation in autumn (1995)}

Hairy vetch developed vigorously after the middle of August, 1995. Though weed emergence was observed in early and mid-August, 1995, almost all weeds were covered with foliage of hairy vetch when mowing. Wheat showed only vegetative growth from July to September because $\mathrm{cv}$. mulchmugi is an autumn sowing variety. But the leaf emerging speed was slow.

When mowing on 17 September, 1995, a large amount of weeds $\left(820 \mathrm{~g} \mathrm{DW} / \mathrm{m}^{2}\right)$ was measured in the field without cover crops (Table 1). Weed growth was suppressed in the hairy vetch field $\left(278 \mathrm{~g} \mathrm{DW} / \mathrm{m}^{2}\right)$. Weed control in the wheat field was smaller than in the hairy vetch field. New weeds did not emerge after weeds and 2 cover crops (hairy vetch and wheat) were mowed by bush cutter on 17 September because the air temperature decreased. The field was covered with dense foliage of hairy vetch after mowing (Fig. 1).

Leafy head weight of lettuce grown in wheat and hairy vetch mulch field was greater than in the bare and tilled field; leafy head weight reached $277 \mathrm{~g}$ in the hairy vetch mulch field (Table 2).

The nitrogen concentration in a leaf of lettuce grown in the bare and tilled field was $3.44 \%$ (Table 3 ). A slightly higher nitrogen concentration $(3.76 \%)$ was observed in a leaf of lettuce

Table 1 Growth of cover crops and weeds (1995) ${ }^{2}$

\begin{tabular}{lcc}
\hline \multirow{2}{*}{ Cover crop } & \multicolumn{2}{c}{ Dry weight $\left(\mathrm{g} / \mathrm{m}^{2}\right)$} \\
\cline { 2 - 3 } & Cover crop & Weed \\
\hline Bare soil & - & $820 \mathrm{a}$ \\
Wheat & 28.8 & $504 \mathrm{~b}$ \\
Hairy vetch & 19.4 & $278 \mathrm{c}$ \\
\hline
\end{tabular}

$\bar{z}$ Values within columns followed by the same letter are not significantly different according to Duncan's multiple range test, $\mathrm{p}=0.05$.

Table 2 Lettuce growth in bare and tilled soil and organic mulch field ${ }^{z}$

\begin{tabular}{lcc}
\hline Mulch & $\begin{array}{c}\text { Leaf } \\
\text { length } \\
(\mathrm{cm})\end{array}$ & $\begin{array}{c}\text { Head } \\
\text { weight } \\
(\mathrm{g})\end{array}$ \\
\hline Bare soil & $14.1 \mathrm{a}$ & $160 \mathrm{a}$ \\
Wheat & $14.9 \mathrm{a}$ & $209 \mathrm{~b}$ \\
Hairy vetch & $16.2 \mathrm{~b}$ & $277 \mathrm{c}$ \\
\hline
\end{tabular}

Values within columns followed by the same letter are not significantly different according to Duncan's multiple range test, $\mathrm{p}=0.05$.

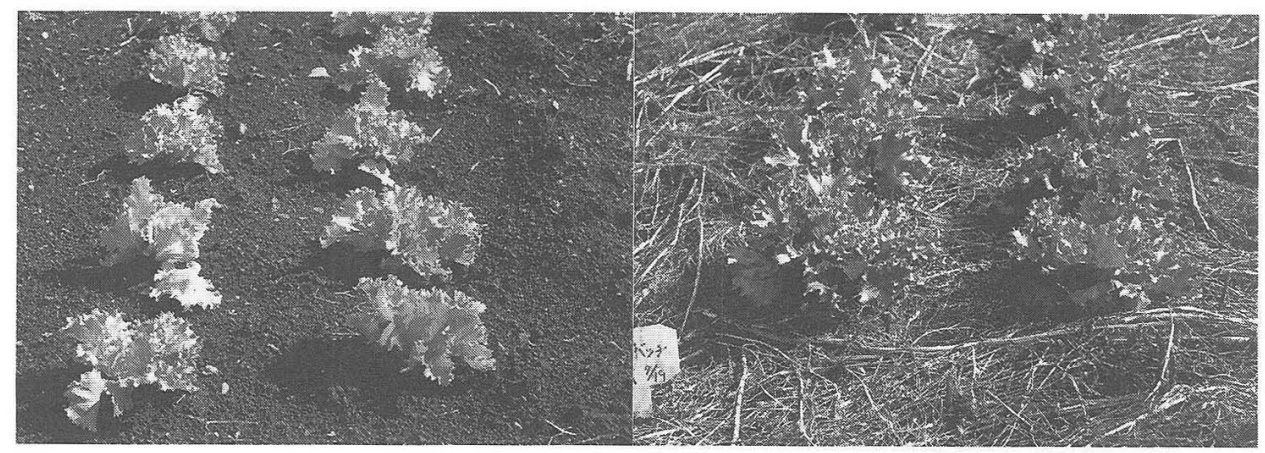

Fig. 1 Lettuce planted in the bare and tilled field (left) and hairy vetch mulch field (right) in 1995. 
Table 3 Nitrogen concentration of soil and lettuce in the bare and tilled field and the hairy vetch mulch field ${ }^{2}$

\begin{tabular}{lcc}
\hline \multicolumn{1}{c}{ Mulch } & $\begin{array}{c}\text { Soil } \\
(\% \text { of DW })\end{array}$ & $\begin{array}{c}\text { Leaf } \\
(\% \text { of DW })\end{array}$ \\
\hline Bare and tillage & $0.70 \mathrm{a}$ & $3.44 \mathrm{a}$ \\
Hairy vetch & $0.69 \mathrm{a}$ & $3.76 \mathrm{~b}$ \\
\hline
\end{tabular}

z Values within columns followed by the same letter are not significantly different according to Duncan's multiple range test, $\mathrm{p}=0.05$.

grown in the hairy vetch mulch field. The nitrogen concentration in the soil covered with the hairy vetch mulch was the same as that of the bare and tilled field.

\section{Soil environment when covered with organic mulch (1996)}

(1) Soil temperature

The diurnal range of soil temperature became small in the soil covered with hairy vetch mulch, compared with that of the bare and tilled field, in mid-summer (3 August), autumn (16 September) and late autumn (22 October), respectively (Fig. 2). On 3 August, although the maximum soil temperature in the bare and tilled field was $32^{\circ} \mathrm{C}$, it was only $27^{\circ} \mathrm{C}$ in the hairy vetch mulch field. Soil temperature was about $20^{\circ} \mathrm{C}$ throughout both day and night on 16 September in the hairy vetch mulch field. On the other hand, the minimum soil temperature in the bare and tilled field showed $11^{\circ} \mathrm{C}$, and increased to $14^{\circ} \mathrm{C}$ in the hairy vetch mulch soil on 22 October.

In the wheat straw mulch field, the diurnal change of soil temperature was small, the same as in the hairy vetch mulch field. Moreover, the maximum soil temperature decreased to $24^{\circ} \mathrm{C}$ on 20 August, against $31^{\circ} \mathrm{C}$ in the bare and tilled field (Fig. 3).

(2) Soil moisture

From the end of the rainy season (23 July), there was good weather throughout July and $\mathrm{Au}$ gust, except for 23 July, 15 August, 23 August and 24 August. The pF was 1.4 on 23 July (Fig. 4). The soil drying was rapid, and the $\mathrm{pF}$ increased after 24 July in the bare and tilled soil, eventually reaching 2.9 , which is not suitable for root growth of tomato plants. Soil drying did not progress in the hairy vetch mulch field in good weather throughout the experiment, and the $\mathrm{pF}$ was 1.8 on 6 August, in spite of no rainfall for 2 weeks.

(3) Mineralization of inorganic nitrogen in soil

The $\mathrm{NH}_{4}$-nitrogen concentration increased until 3 days after incubation, and the $\mathrm{NO}_{3}$-nitrogen concentration increased gradually in any soil (Fig. 5). According to the change of nitrogen concentration, the inorganic nitrogen was supplied from the organic nitrogen in the soil examined. The concentration of $\mathrm{NO}_{3}-\mathrm{N}$ in the wheat and hairy vetch mulch soil was higher than in the bare and tilled soil ; the difference in nitrogen concentration between the two mulch soils was not significant.

\section{Weed control and crop yield in no-tillage field} covered with organic mulch (1996)

(1) Weed control

In July and August, $343 \mathrm{~g} / \mathrm{m}^{2}$ of weed (Dry weight) emerged on the bare and tilled field (Fig. 6). The weed quantity decreased in the field covered with the wheat and hairy vetch compared
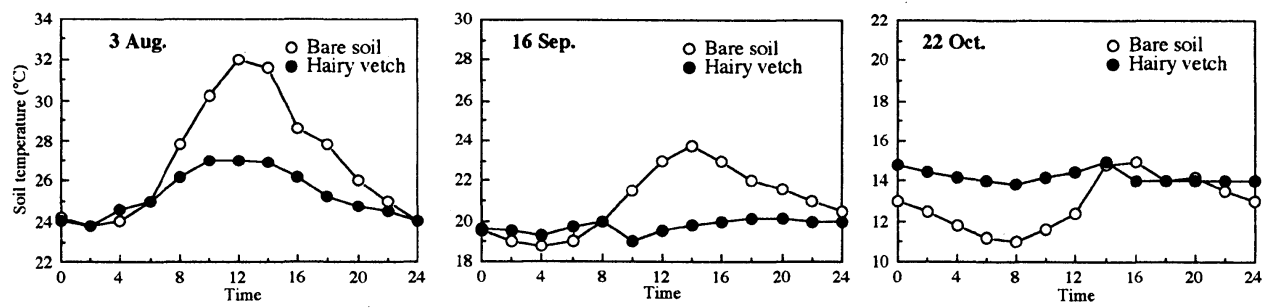

Fig. 2 Change of soil temperature when covered with hairy vetch mulch 

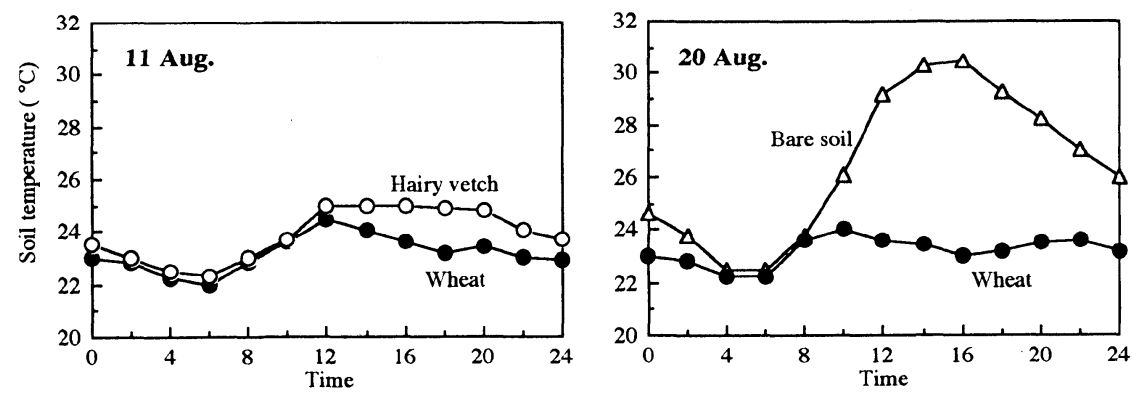

Fig. 3 Change of soil temperature when covered with hairy vetch mulch and wheat mulch
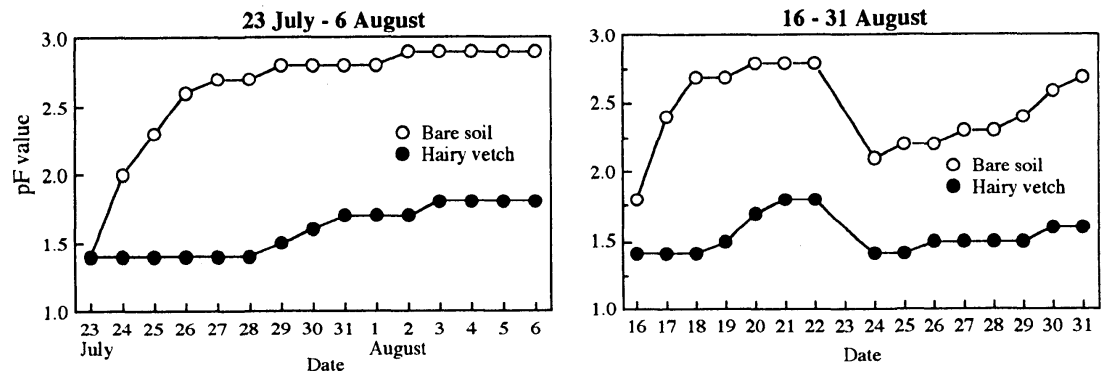

Fig. 4 Change of $\mathrm{pF}$ value in the soil covered with or without hairy vetch mulch.

(Rainfall : $52 \mathrm{ml}$ at $23 \mathrm{July}, 28 \mathrm{ml}$ at 15 August, $27 \mathrm{ml}$ at 23 August, $33 \mathrm{ml}$ at August)
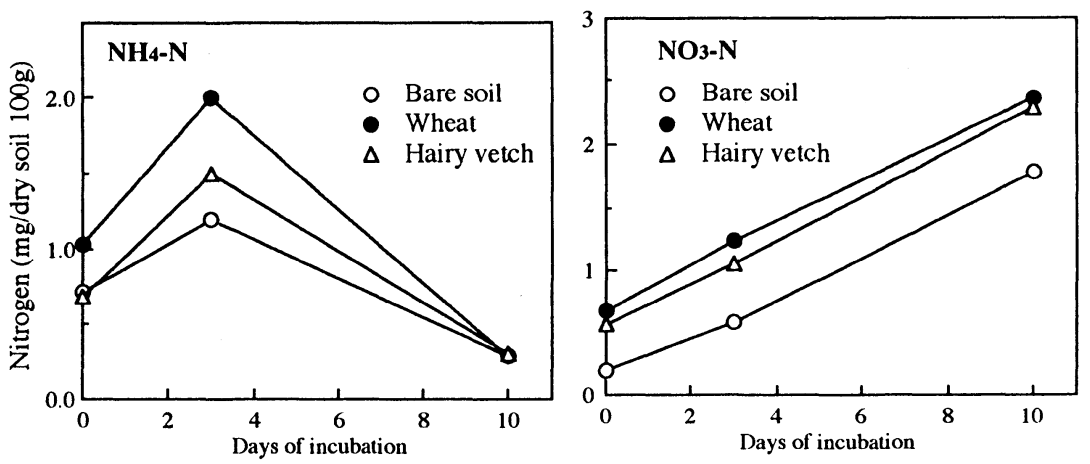

Fig. 5 Change of nitrogen minerazation in soil with or without organic mulch.

with the bare and tilled field, reaching $17 \mathrm{~g} / \mathrm{m}^{2}$ (Dry weight) in the hairy vetch mulch field, approximately $1 \mathrm{~cm}$ of plant residue thickness. Weed control was $53 \%$ in the wheat straw mulch field compared with the bare and tilled field. Lateral shoots developed from the wheat stubble.

(2) Crop yield

Vegetable seedlings could be transplanted to the no-tillage soil covered with hairy vetch mulch because the mulch was soft and no stubble was left. Three vegetable seedlings planted in the hairy vetch mulch field grew vigorously compared with the bare and tilled field and the wheat straw mulch field. The yield of each of the 3 vegetables in the hairy vetch mulch field was significantly higher than in those of the 
other fields (Fig. 7). The pod weight/10 plants and fruit weight/plant showed $485 \mathrm{~g}$ in pod soybean and $490 \mathrm{~g}$ in tomato cultivated in the hairy the vetch mulch field. These yields were approximately more than 1.5 times or twice that of plants cultivated in the bare and tilled field and the wheat straw mulch field. The yield of the vegetables grown in the wheat straw mulch field was the same as those grown in the bare and tilled field in pod soybean and tomato.

The yield (fresh leaf weight) of butter head lettuce showed $42 \mathrm{~g}$ in the hairy vetch mulch field, 6 times that of the plants cultivated in the

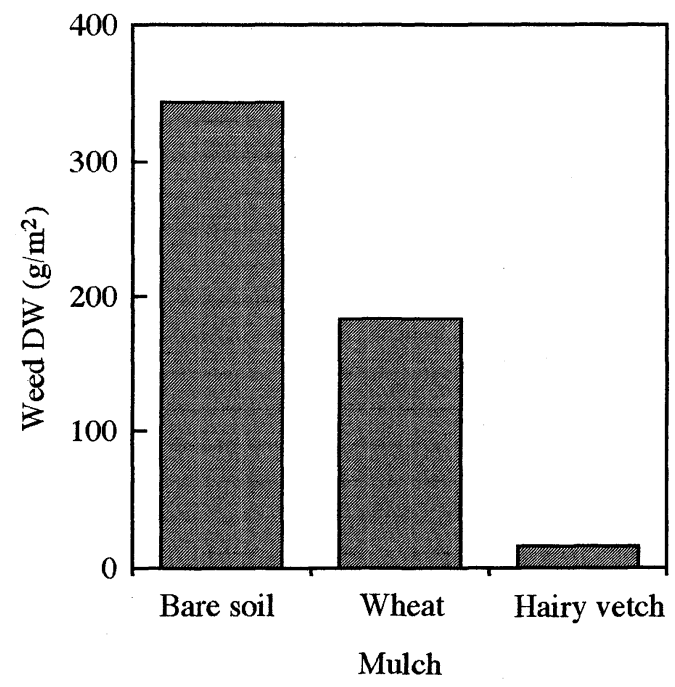

Fig. 6 Dry weight of weed emerged in July and August, 1996. bare and tilled field, and its yield in the wheat straw mulch was higher as well.

\section{Discussion}

Some data obtained in the present examination support the previous reports describing the soil environment when covered with organic mulch (plant residue)

Organic mulches generally decrease maximum but increase minimum soil temperature ${ }^{8,17)}$. Bare soil temperature rises $30^{\circ} \mathrm{C}$ in mid-summer and decreases to about $10^{\circ} \mathrm{C}$ in late autumn in Muramatsu, Niigata Prefecture. The optimum soil temperature for plant growth is known to change owing to the growth stage of vegetables, and tends to decrease as plants grow older. In general, high soil temperature near $30^{\circ} \mathrm{C}$ inhibited plant growth in most vegetables, except for melon, watermelon and cucumber. For plant growth, $25^{\circ} \mathrm{C}$ in tomato ${ }^{18)}, 18-23^{\circ} \mathrm{C}$ in soybean and $13-18^{\circ} \mathrm{C}$ in lettuce are suitable temperatures ${ }^{19}$. The hairy vetch mulch cooled in mid-summer and warmed in late autumn, so the soil temperature was close to optimum for plant growth. Besides, the soil temperature becomes stable under hairy vetch mulch conditions.

Hairy vetch desiccated mulch showed the effect of soil water retention. Soil water condition $(\mathrm{pF} ; 1.4-1.8)$ formed in the hairy vetch mulch field was good for tomato growth, because $\mathrm{pF}$ 1.5-2.0 is recognized to be suitable for tomato growth after transplanting in open field ${ }^{20)}$. How-
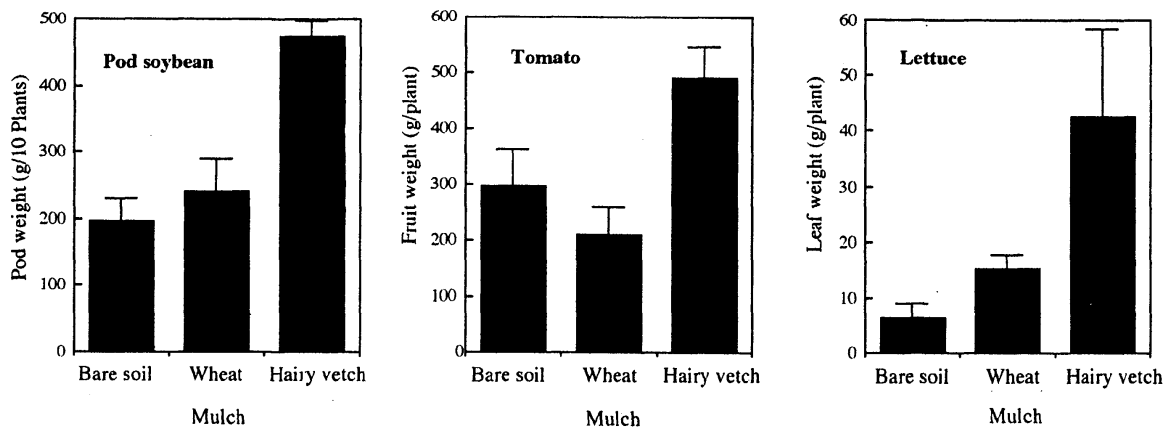

Fig. 7 Yield of 3 vegetables grown in bare soil and organic mulch field. Vertical bar indicates standard error. 
ever, soil moisture is concerned with fruit quality, and soil water maintained under the organic mulch has to be estimated by the fruit quality of vegetables.

Increase of yield was recognized in any vegetable used in the examination. The increase of lettuce yield in late autumn of 1995 showed that more suitable growing conditions for lettuce are provided by the no-tillage and hairy vetch mulch, compared with the bare and tilled soil, because serious weed damage did not occur in any fields used and nitrogen absorption was increased in the lettuce grown in the hairy vetch mulch field in late autumn. It was reported that winter legume crops such as hairy vetch and crimson clover provided more $\mathrm{N}$ equivalent, approximately $100 \mathrm{~kg} \cdot \mathrm{ha}^{-1}$ in the conserved tillage $^{13,21)}$. The mineralization of organic nitrogen in the soil covered with the hairy vetch mulch was also expected in this experiment. Further investigation is needed to determine the nitrogen supplying effect in the soil when covered with organic mulch.

It was supposed that weed emergence strongly affected the yield of the 3 vegetables in 1996. In tomato and pod soybean, which take a long time until harvest of mature fruit and edible bean, the yield decreased remarkably in the bare and tilled field and the wheat mulch field because of the greater weed quantity than in the hairy vetch mulch field. Besides, new lateral shoots developed from the stubbles of wheat mowed, and the possible nutritional competition between wheat with new lateral shoots and vegetables planted in the wheat straw mulch field was also a factor. On the other hand, butter head lettuce rapidly grows to harvest size in a relatively short period, and weed damage was small during growth. The difference in weed quantity between the wheat straw mulch and the hairy vetch mulch was supposed to be caused by ground cover ability, shading of ground-surface and decomposing speed of plant residue. Such characteristics will be investigated in order to determine useful cover crops. Nowadays, to 'pre- vent environmental disruption, the development of chemical mulch film with easy decomposing ability in the field is much anticipated. Organic mulch is very useful because of its natural decomposing ability.

In some crop production with organic mulch in Japan, yields of sweet corn and watermelon produced in the no-tillage field with hairy vetch mulch were the same as those of the tilled and bare soil and the wheat straw mulch field ${ }^{15}$. Japanese apricot showed greater fruit weight and yield in mulch and no-tillage field ${ }^{16)}$.

It is well known that the no-tillage system leads to saving energy ${ }^{22}$. However, when sowing the seeds of some crops in the no-tillage field, seed germination was not often observed to be uniform in some practices ${ }^{23}$. In the present investigation, transplanting of vegetables were used to estimate the plant growth in the organic mulch and no-tillage field to prevent lack of uniformity in seedling growth. Recently, pod soybeans are transplanted into the field at the juvenile stage (with 2 leaves) in Niigata Prefecture. Field crops which are usually sown in the soil directly, such as corn and sorghum, were produced in the examination under legume organic mulch and no-tillage condition ${ }^{13,24)}$. It is now necessary to establish a seeding technology for field crop production in the organic mulch and no-tillage field.

Conventionally, mulching effect and notillage effect on soil environment and crop development have been investigated separately. The cropping system combined with organic mulch and no-tillage in the present examination introduced new cultivating conditions for crop growth and human work. Besides, utilization of plant residue mulch, not chemical film mulch, is one of the field management utilizing plant function and mineralization of organic nitrogen by decomposing of legume plant residues in present examination. The present cropping system with organic mulch and no-tillage will be evaluated as one form of sustainable agriculture. Further investigation of cropping techniques and crop 
growth are needed for the establishment of this system.

\section{Acknowledgement}

The authors wish to thank Dr. M. Nonaka, Fac. Agriculture, Niigata University, for his advice on nitrogen analysis and Messrs. Y. Yamashita, Y. Matsuo, T. Yamazaki, M. Watanabe, M. Ishimoto and T. Sato, University Farm, Niigata University, for their technical support in vegetable cultivation. The research reported in this publication was supported in part by Grant-inaid (No. 07306012) from the Ministry of Education, Science, Sports and Culture, Japan.

\section{Literature Cited}

1) Nitta, T. (1993) Agricultural technologies harmonized with ecological system in Europe and United States. J. Agricultural Science $48: 49-54$. (In Japanese)

2 ) Ganno, K. (1994) The ideal way of farm work aiming at sustainable agriculture. Japan. J. Farm Work Res. 29:1-6. (In Japanese)

3 ) Scott, T. W. and J. M. Pleasant, R. F. Burt and D. J. Otis. (1987) Contribution of ground cover, dry matter, and nitrogen from intercrops and cover crops in a corn polyculture system. Agron. J. 79 : 792-798.

4 ) Blevins, R. L. and W. W. Frye. (1993) Conservation tillage: an ecological approach to soil management. Advances in Agronomy $51: 33-78$.

5 ) Stivers, L. J. and C. Shennan. (1991) Meeting the nitrogen needs of processing tomatoes through winter cover cropping. J. Production Agr. $4: 330-335$.

6 ) Smith, S. J. and A. N. Sharpley. (1993) Nitrogen availability from surface-applied and soil-incorporated crop residues. Agron. J. $85: 776-778$.

7 ) Munawar, A., R. L. Blevins, W. W. Frye and M. R. Saul. (1990) Tillage and cover crop management for soil water conservation. Agron. J. $82: 773-777$.
8 ) Teasdale, J. R. and C. L. Mohler. (1993) Light transmittance, soil temperature and soil moisture under residue of hairy vetch and rye. Agron. J. 85 : 673-680.

9 ) Teasdale, J. R. and A. A. Abdul-Baki. (1995) Soil temperature and tomato growth associated black polyethylene and hairy vetch mulch. J. Amer. Soc. Hort. Sci. 120 : 848-853.

10) Teasdale, J. R. and C. S. T. Daughtry. (1993) Weed suppression and desiccated hairy vetch (Vicia villosa). Weed Science $41: 207$ 211.

11) Worsham, A. D., G. G. Nagabhushana and J. P. Yenish. (1995) The contribution of notillage crop production to sustainable agriculture. Proc. 15th Asia-Pacif. Weed Sci. Conf. 104-111.

12) Donn, G. S., A. W. Douglas and A. D. David. (1986) Influence of mulch, tillage and diphenamid on weed control, yield and quality in no-till flue cured tobacco. Weed Science 34 : 738-744.

13) Blevins, R. L., J. H. Herbek and W. W. Frye. (1990) Legume cover crops as a nitrogen source for no-till corn and grain sorghum. Agron. J. $82: 769-772$.

14) Abdul-Baki A. A. and J. R. Teasdale. (1993) A no-tillage tomato production system using hairy vetch and subterranean clover mulch. HortScience 28: 106-108.

15) Fujii, Y., M. Iwasaki, H. Akiyama and T. Wakou. (1995) Corn and watermelon production with hairy vetch mulch in relation to weed suppression. Weed Research, Japan 41 (supplement 1) : 78-79. (In Japanese)

16) Yamagishi K. and Y. Gemma. (1996) Assessment of a no-tillage and mulch farming with fruit cropping. (1) Growth and yield of some crops and physical and chemical properties of the soil. Japan. J. Farm Work Res. 31: 103-116. (In Japanese)

17) Ashworth, S. and H. Harrison. (1983) Evaluation of mulches for use in the home garden. Hort Science 18 : 180-182.

18) Cooper, A. J. (1973) Influence of rooting- 
medium temperature on growth of Licopersicon esculentum. Ann. Appl. Biol. 379-385.

19) Tachibana, S. (1992) Environment of root zone and vegetable growth. Ito, T., eds. in 'Vegetable science' 172-230. Kawashima Shoten, Tokyo. (In Japanese)

20) Uemoto, N. (1990) Cultivation for summer and autumn harvest in open field. Vegetable encyclopedia 2. Tomato p.253-268. Nobunkyo, Tokyo. (In Japanese)

21) Hargrove W. L. (1986) Winter legumes as a nitrogen source for no-till grain sorghum. Agron. J. 78: 70-74.

22) Sakai, N. (1988) A review of no-tillage farmwork (2) Change in soil properties and characteristics of farm work. Japan. J. Farm
Work Res. 24 : 1-9. (In Japanese)

23) Kanazawa, S. (1995) The no-tillage cropping system as the agriculture for sustaining and environmental preservation - crop yield and soil characteristics - Japan. J. Soil Sci. Plant Nutri. 66 : 286-297

24) Holderbaum, J. F., A. M. Decker, J. J. Meisinger, F. R. Mulford, and L. R. Vough. (1990) Fall seeded legume cover crops for notillage corn in the humid east. Agron. J. 82: $117-124$

\section{Keywords :}

organic mulch, no-tillage, soil temperature, soil moisture, weed prevention, nitrogen mineralization, hairy vetch, wheat

\title{
オーガニックマルチ・不耕起システムにおける土壤特性と野菜の試作
}

\author{
荒木 肇・伊藤道秋
}

\section{摘 要}

1995年 7 月に緑肥用コムギと 1 年性マメ科牧草の ヘアリーベッチを栽培し，9月に刈り倒して「オー ガニックマルチ・不耕起」状態で結球型レタスを無 肥料で試作すると，無マルチ耕耘圃場・コムギマル 千圃場（出穂せず茎葉の残渣）・ヘアリーベッチマ ルチ固場の順に収量が増加した。

1996年春季にコムギは出穂し，へアリーベッチは 荃葉を繁茂させたので，6月に再度刈り倒して「オ 一ガニックマルチ・不耕起」状態を作り，土壤環境 を調查して，3種野菜を無肥料で試作した。オーガ ニックマルチ圃場の地温は無マルチ耕耘围場より安 定し，夏季や初秋では地温を低下させ，晚秋には地 温を上昇させた。土壤水分に関して，地中 $15 \mathrm{c} \mathrm{m} の$ $\mathrm{pF}$ 值は無マルチ耕䎣圃場では梅雨終了後急速に上 昇したが，へアリーベッチマルチ圈場では $\mathrm{pF} 1.5$
1.8に維持され, 保水性が示された。オーガニック マルチ下の土壤を10月に採集して培養すると，無機 化窒素量は無マルチ耕耘围場に比べて多かった。 7 ～8月に発生した雑草量は無マルチ耕耘圃場に比べ て，コムギマルチ戋場では $53 \%$ に減少し，へアリー ベッチマルチ戋場では約 $5 \%$ に減少した。へアリー ベッチマルチ戋場で無肥料栽培したトマト・エダマ メ・サラダナの収量は他より有意に高かった。

キーワード :

オーガニックマルチ, 不耕起, 地温, 土壤水分, 窒素無機化，雑草抑制，へアリーベッチ，コムギ 